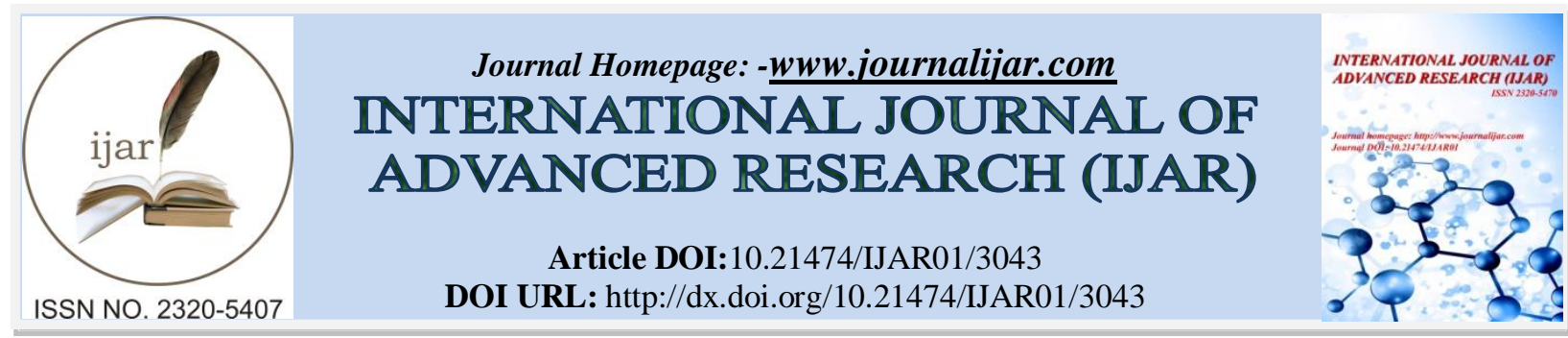

RESEARCH ARTICLE

\title{
THE MODEL OF BEEF CATTLE BREEDING DEVELOPMENT WITH HOUSEHOLD ECONOMIC APPROACH IN JEMBER REGENCY.
}

\author{
Nanang Dwi Wahyono ${ }^{1}$, Zaenal Fanani ${ }^{2}$, and Bambang Ali Nugroho ${ }^{2}$ and Moch Nasich². \\ 1. Student ofPostgraduate Program of Doctorate in Animal Husbandry, Brawijaya University. \\ 2. Lecturer of Animal Husbandry, Brawijaya University.
}

\section{Manuscript Info}

Manuscript History

Received: 30 November 2016

Final Accepted: 28 December 2016

Published: January 2017

Key words:-

Household, policy, breeding

\section{Abstract}

The analysis in specific aims was using Gaduhan Model that was considered as suitable to the existing conditions in Jember Regency. Some analyses would be used in this research, and these included Analysis of Regression, Individually Coefficient Test (t-test), Simultaneously Coefficient Test (F-test), and Classical Assumption Test. Result of research had given some results. (1) Household economic model could explain the behavior of deciding the production of farming and breeding. This decision was influential to the income of farmer household. This decision was numerous, including that about grass-collection worker, on-family breeding worker, concentrate cost, green feed cost, off-family rice-field farming worker, on-family ricefield farming worker, rice-field fertilizer cost, income from rice-field farming, off-family garden farming worker, on-family garden farming worker, income from garden farming, income from beef cattle breeding, income of the family, income from garden field, total cost of rice-field farming, and income from rice-field farming. (2) Income from beef cattle breeding was influenced by the number of beef cattle bred and the number of grass-collection worker. The cost of concentrate was influenced by the purchasing cost for livestock feed greens (HMT). Therefore, HMT cost would be influenced by the number of beef cattle bred. (3) If governmental policy was designated to improve the income of farmer household, then the most effective policy scenario would be the scenario of providing financial aid for rice-field farming at rate of $\mathrm{Rp} 1,000,000$.-. The allocation for each decision was set at percentage point, such as: Grass-collection worker $(0.04 \%)$; On-family breeding worker $(0.24 \%)$; Cconcentrate cost $(0.00 \%)$; Green feed cost $(0.00 \%)$; Off-family rice-field farming worker $(439.00 \%)$; On-family rice-field farming worker $(45.31 \%)$; Rice-field fertilizer cost $(4.42 \%)$; Income from rice-field farming (7.25\%); Off-family garden farming worker (34.07\%); On-family garden farming worker $(0.00 \%)$; Income from garden farming (1.593\%); Income from beef cattle breeding $(0.00 \%)$; Income of the family (30.33\%); Income from garden field (1.76\%); Total cost of ricefield farming (44.40\%); Income from rice-field farming (25.85\%); and Garden farming worker (5.94\%). (4) If the government could select 
the proper policy, then policy goal would be conforming to the result of this research, respectively the improvement of household income.

Copy Right, IJAR, 2016,. All rights reserved.

\section{Introduction:-}

Beef was animal-based protein source. It stood as one of agents of development that determined the competitiveness of human resource at certain nation. The consumption of animal protein by Indonesia commnity was still lower compared to other ASEAN countries. Beef consumption was still driven on demand, and the fulfillment was always problematic. A gap between consumption demand for local beef and its production occured annually. The possible cause was the growth of the middle-to-upper class population. This increasing demand was reflected in the increased beef consumption from $1.95 \mathrm{~kg}$ per capita on 2007 to $2 \mathrm{~kg}$ per capita on 2008. This rate was still ascending to 2.24 $\mathrm{kg}$ per capita on 2009. This consumption increase might impact on the increasing demand for beef and internals, precisely from 455,755 tones on 2008 to 516,603 tons on 2009 . Such beef demand was equivalent to the number of 2.432 millions beef cattle bred on 2008 and 2.746 millions beef cattle on 2009. Fulfilling this demand, the imported beef and internals were also advancing toward 110.246 tones. The imported origin cattle (calf) also upsurged to the rate of 768,133 calves on 2009. Import measure was taken because local beef cattle only supplied $49 \%$ beef demand of national beef demand on 2009.

\section{Study Method:- \\ Research Sample:-}

The sample of farmer was selected based on some conditions. Farmer must have minimally one beef cattle to breed. Beef cattle must be prime or adult, and had been grown at least one year. The breeder must have experience minimally at least three years in breeding.

\section{Data Analysis Method:-}

Some analyses methods were used in this research.

$$
\begin{aligned}
& \text { Analysis of Regression:- } \\
& \mathrm{Y}=\mathrm{b} 0+\mathrm{b} 1 \mathrm{X} 1+\mathrm{b} 2 \mathrm{X} 2+\mathrm{b} 3 \mathrm{X} 3+\mathrm{b} 4 \mathrm{X} 4+\mathrm{b} 5 \mathrm{X} 5+\mathrm{b} 6 \mathrm{X} 6+\mathrm{b} 7 \mathrm{X} 7+\mathrm{b} 8 \mathrm{X} 8+\mathrm{b} 9 \mathrm{X} 9+\mathrm{b} 10 \mathrm{X} 10+\mathrm{e}
\end{aligned}
$$

Where:-
Y
B
X1
X2
X3 :
X4
X5
X 56
X7
X8
X9
X10
e

Number of beef cattle bred Coefficient of regression

Age of breeder

Breeding experience of breeder

Education background of breeder

Land width occupied for beef cattle breeding

Income of beef cattle breeder

Price of the origin calf

Price of the concentrate

Feed consumption

Non-feed consumption

Development pattern $(0=$ Fattening, $1=$ Origin calf $)$

Disturbance term

Individually Coefficient Test (t-test)

Ho : bi $=0 \quad(i=1,2, \ldots, 10)$

$\mathrm{Ha}: \mathrm{bi} \square 0$

By determining degree of confidence at $95 \%(\square=0,05)$, and also degree of freedom at (Df) $=\mathrm{n}-\mathrm{k}-1$, then t-table could be set and used as the reflection of region that accepted or rejected hypothesis. The $t$-count rate could be obtained using the following equation: 
$t=\frac{b_{i}}{S b_{i}}$

where :

$\mathrm{bi}=$ coefficient of regression of independent variable $\mathrm{i}$.

$\mathrm{Sbi}=$ standard error of coefficient of regression bi

Opportunity value ( $\mathrm{p}$-value) that was obtained from $\mathrm{t}$-test was then compared with $\alpha$ by using the following criteria:

$>$ If $\mathrm{p}$-value $>\alpha$, then Ho was accepted, meaning that there was a significant effect from independent variable on dependent variable.

$>$ If $\mathrm{p}$-value $<\alpha$, then Ho was rejected, meaning that there was no significant effect from independent variable on dependent variable.

Simultaneoulsy Coefficient Test (F-test)

Ho : $\beta_{1}=\beta_{2}=\ldots=\beta_{10}=0$

$\mathrm{Ha}:$ there must be minimally one $\mathrm{i}$ where $\beta_{\mathrm{i}} \neq 0(\mathrm{i}=1,2, \ldots, 10)$

By setting the degree of confidence at $95 \%(\alpha=0,05)$ and degree of freedom at (Df) $=k /(n-k-1)$, then F-table could be measured to be used as the reflection of region that accepted or rejected hypothesis. The F-count rate was derived from the following equation:

$F=\frac{R^{2} /(k)}{\left(1-R^{2}\right) /(n-k-1)}$

Opportunity value (p-value) from F-test was compared with $\alpha$ through some criteria as following:

$>$ If p-value $>\alpha$, then Ho was accepted, meaning that there was no significant and simultaneous effect of all independent variables on dependent variable.

$>$ If $\mathrm{p}$-value $<\alpha$, then Ho was rejected, meaning that there was significant and simultaneous effect of all independent variables on dependent variable.

Classical Assumption Test:-

Classical assumption test helped determining whether an estimation had the required characteristics, such as unbiasedness, consistency, sufficiency, and others. Therefore, the estimated coefficient of regression would be the best linear estimator due to its unbiasedness (Best Linear Unbiased Estimator = BLUE) but if it could meet some classical assumptions. In reality, classical assumptions were failed to be met and therefore, further test was conducted to examine how far these classical assumptions could be fulfilled.

According to Gujarati (2001), multiple linear regression model with OLS method could be used as unbiased estimator if it met BLUE requirements, such as:

$>B e s t=$ It gave the best coefficient of regression.

$>$ Linier $=$ Independent variables were linearly related with dependent variable.

$>$ Unbiased $=$ The expectancy rate of coefficient of regression was similar to its actual rate (bi).

$>$ Efficient estimator $=$ The obtained regression model had minimum variance.

\section{Normality Test:-}

It was conducted by comparing opportunity rate (p-value) from Anderson Darling Test with $\alpha$ on several conditions:

- If $p$-value $>\alpha$ then $\mathrm{H}_{0}$ was accepted.

- If $p$-value $<\alpha$ then $\mathrm{H}_{0}$ was recejted.

Where $\mathrm{H}_{\mathrm{o}}=$ normally dispersed data

$\mathrm{H}_{\mathrm{a}}=$ abnormally dispersed data 


\section{Multicollinearity Test:-}

Whether multicolinearity test did exist or not was detected by the following methods:-

1. Coefficient of determination (R2) was high, and t-value from the estimated regression of all variables was significant.

2. If R2 must be very high (more than 0.8 ), and no coefficient of regression was statistically significant, then there would be multicollinearity symptom.

3. Variance Inflation Factor (VIF) was examined, where if VIF stood below 10, it meant that multicollinearity symptom did not exist.

\section{Heteroscedasticity Test:-}

Heteroscedasticity occured because the variance of the residual was not similar across each observation. It was tested using Glejser Test. If the significance rate of Glejser score was lower than 0.05 (5\%), then the regression equation contained heteroscedasticity. Converse result would be no indication of heteroscedasticity or homoscedasticity.

\section{Auto-correlation Test:-}

Detecting whether there was auto-correlation was using Durbin Watson Model. It was explained as following:

1. OLS Regression was operated to obtain residual $e_{i}$.

2. Term $d$ was counted with the following formula:

$$
d=\frac{\sum_{t=2}^{t=N}\left(e_{1}-e_{t-1}\right)^{2}}{\sum_{t=1}^{t=N} e_{t}^{2}}
$$

3. For certain sample size, with many explanatory variables, critical rates of $d L$ dan $d U$ were estimated

4. If $\mathrm{d}$ remained between $d U$ and 4- $d U$, then non-auto-correlation assumption was met. If $\mathrm{d}$ stood between 0 and $d L$, then there would be positive auto-correlation, while if $d$ existed between $4-d L$ and 4 , then there must be negative auto-correlation.

5. The assumption of no occurence of auto-correlation was met if Durbin-Watson statistic rate was found between $\mathrm{dU}$ and 4-DU.

Simultaneous Equation System Model:-

Simultaneous Equation System Model was used as the cecond analysis technioque to answer the second goal from the model of simulation for the policy of beef cattle breeding development, that in this case must be made compatible to the existing condition. The specification of this model included several items:

The use of worker at farming work;-

Worker who was used at farming work was divided into three groups, such as: breeding worker, rice-field farming worker, and garden farming worker. The use of on-family breeding worker (TKSPDKL) was estimated to be influenced by household member (ARTP), number of beef cattle (JSP), and family income (INCKL). The structural equation covering all these items was written as:

TKSPDKL $=$ B0 + B1*ARTP + B2*JSP + B3*INCKL + B4*D;

Worker for rice-field farming was assigned into two groups, off-family rice-field farming worker (TKUTLKL) and on-family rice-field farming worker (TKUDKL). Off-family rice-field farming worker was estimated to be influenced by occupied land width (LHN), income from rice-field farming (KUT), and family income (INCKL). Onfamily rice-field farming worker (TKUDKL) was estimated under influence of occupied land width (LHN) and income from rice-field farming (KUT). The structural equation was described as following:

TKUTLKL $=\mathrm{F} 0+\mathrm{F} 1 * \mathrm{LHN}+\mathrm{F} 2 * \mathrm{KUT}+\mathrm{F} 3 * \mathrm{INCKL}+\mathrm{F} 4 * \mathrm{D} ;$

TUTDKL $=\mathrm{G} 0+\mathrm{G} 1 * \mathrm{LHN}+\mathrm{G} 2 * \mathrm{KUT}+\mathrm{G} 3 * \mathrm{D}$;

Worker for garden farming (TKBUN) was also separated into two, respectively off-family garden farming worker (TKBUNLKL) and on-family garden farming worker (TKBUNDKL). Off-family garden farming worker (TKBUNLKL) was estimated to be influenced by occupied land width (LHN) and off-family rice-field farming 
worker (TKUTLKL). On-family garden farming worker was estimated under influence of occupied land width (LHN). Structural equation was written as:

TKBUN $=$ TKBUNDKL + TKBUNLKL;

TKBUNLKL $=\mathrm{J} 0+\mathrm{J} 1 *$ LHN $+\mathrm{J} 2 *$ TKUTLKL $+\mathrm{J} 3 * \mathrm{D}$

$\mathrm{KBUNDKL}=\mathrm{K} 0+\mathrm{K} 1 * \mathrm{LHN}+\mathrm{K} 2 * \mathrm{D}$;

\section{Cost for Beef Cattle Breeding:-}

Total cost of beef cattle breeding (TBSP) was comprised of variable cost and fixed cost. Variable cost included the cost for beef cattle concentrate (BKONSP), the cost for beef cattle medicine (BOBTSP), the cost for green feed (BHMT), the cost for origin calf (HABIT) and the cost for other structure and infrastructure (BSPL). The equation was arranged as:

TBSP $=$ BKONSP + BOBTSP + BHMT + HABIT + BSPL

Income From Beef Cattle Breeding:-

Annual income from beef cattle breeding (KSP) was obtained from the summation of all incomes that related with beef cattle breeding (RESP), and then, it was subtracted with the total cost of beef cattle breeding (TBSP). Monthly income from beef cattle breeding was derived by dividing the profit of beef cattle breeding in a year (KSP) with the number of months in a year. Therefore, the equation was written as:

KSP $=$ RESP - TBSP;

$\mathrm{KSPBLN}=\mathrm{KSP} / 12$;

Incomes that related with beef cattle breeding (RESP) was estimated to be influenced by the number of beef cattle bred (JSP), the quantity of concentrate (JKON), and the grass-collection worker for beef cattle (TKSPRMP). The structural equation was written as following:

$\mathrm{RESP}=\mathrm{E} 0+\mathrm{E} 1 * \mathrm{JSP}+\mathrm{E} 2 * \mathrm{JKON}+\mathrm{E} 3 * \mathrm{TKSPRMP}+\mathrm{E} 4 * \mathrm{D} ;$

Identification of Model in the Simultaneous Equation System:-

Model must be identified before making an estimation. The aim was to facilitate the determination of estimation method. There were three types of model identification, such as (1) under identified or unidentified, (2) exactly identified, and (3) over identified. If a certain equation system was said as under identified, there would no statistical models be used to estimate all parameters in simultaneous equation model. If the equation was considered exactly identified, the most proper technique was indirect least squares (ILS). If simultaneous equation was called as over identified, then various techniques could be used such as Two stage least square (2SLS), Three stage least square (3SLS), Limited Information Maximum Likelihood (LIML), or Full Information Maximum Likelihood (FIML). Indeed, 2SLS method was the most frequently used because it was compatible with software SAS.

Identification was conducted in two methods. First was testing the structural model (order condition), while the second was testing against model in reduced form (rank condition). Because first method was more simple and more easier, then the study of dissertation preferred to use first method. The condition to say certain equation as identified was that the number of variable excluded from the equation, but included within other equation, must be minimally equal to the number of equation in the simultaneous equation model after being subtracted with one. It was written as following (Gujarati, 2000).

The equation would be identified if (K-M) $\geq(\mathrm{G}-1)$

where:

$\mathrm{G}:$ number of equation (endogenous variable)

$\mathrm{K}:$ number of variable in the model (endogenous and predetermined)

$\mathrm{M}$ : number of variable (endogenous dan exogenous) in the identified equation

The conditions of the equation could be exposed into the details as following:

1. If $(\mathrm{K}-\mathrm{M})<(\mathrm{G}-1)$ then the equation was considered as under identified

2. If $(\mathrm{K}-\mathrm{M})=(\mathrm{G}-1)$ then the equation was considered as exactly identified

3. If $(\mathrm{K}-\mathrm{M})>(\mathrm{G}-1)$ then the equation was considered as over identified 


\section{Identification of Model in the Simultaneous Equation System:-}

Model identification was conducted before making an estimation. This process was aimed to facilitate the determination of estimation method. There were three types of model identification: (1) under identified or unidentified, (2) exactly identified, and (3) over identified.

\section{Model Validation;-}

Model validation was carried out to understand whether endogenous variable in the simultaneous equation model could be used to describe the information that was not different from actual rate.

\section{Policy Simulation:-}

Recent governmental policy was designated to provide working capital aid to the breeders through the direct loan aid to the community (BPLM). This aid was given to the breeder group who was seriously attended by policy maker. To ensure the benefit of this governmental policy, this research attempted to simulate household economic policy, involving some policies such as: (1) feed consumption, (2) non-feed consumption, (3) production cost for beef cattle breeding, (4) production cost for rice-field farming. Household economic model of beef cattle breeders was made from simultaneous equation system.

\section{Result:-}

Income That Related with Beef Cattle Breeding (RESP):-

The sign of explanatory variable in the equation of all incomes that related with beef cattle breeding at Gaduhan Pattern (RESP) was compatible with the expectancy and economical behavior from the worker who maintain the number of beef cattle bred (JSP) and also from the grass-collection worker (TKSPRM). Therefore, the income of beef cattle breeding at Gaduhan Pattern (RESP) was influenced by the number of beef cattle bred and the number of grass-collection worker. The greater number of beef cattle bred, the greater also be obtained the incomes from beef cattle breeding at Gaduhan Pattern in Jember Regency. The higher ownership rate for beef cattle was closely related with not too high production input cost. It conflicted with the finding in the ownership scale below five beef cattles. Great number of beef cattle bred would minimize the loss due to unreliable production input. Grass-collection worker was one determinant in this situation. Greater number of grass-collection worker at Gaduhan Pattern would reduce the income of beef cattle breeding at Gaduhan Pattern because production input cost was not efficient, possibly due to the excessively high cost to expend in production input. It definitely decreased farmer income.

Result of regression against the income from beef cattle breeding was shown in the table. The equation of regression was written as:

RESP $=480.804+15961.7 \mathrm{JSP}+0.146$ BKONSP- 1719.25TKSPRM+33.461 D

Table:- Result of Regression Analysis on The Income from Beef Cattle Breeding

\begin{tabular}{|l|c|c|c|c|}
\hline \multicolumn{1}{|c|}{ Variable } & $\begin{array}{c}\text { Parameter } \\
\text { Estimation }\end{array}$ & Standard Error & t-value & $\operatorname{Pr}>|\mathrm{t}|$ \\
\hline JSP & 15961.700 & 598.074 & 26.690 & $<.0001$ \\
\hline BKONSP & 0.146 & 0.171 & 0.850 & 0.402 \\
\hline TKSPRMP & -1719.250 & 748.817 & -2.300 & 0.030 \\
\hline $\mathrm{D}$ & 33.461 & 436.044 & 0.080 & 0.939 \\
\hline $\mathrm{F}-\mathrm{y}$ alue $=771.83$ & \multicolumn{3}{|l}{} \\
$\mathrm{Pr}>\mathrm{F}=<0.0001$ & \multicolumn{5}{|l|}{} \\
$\mathrm{R}^{2}=0.99133$
\end{tabular}

Source: Analysis on Primary Data, 2016

The above table showed that parameters were tested partially (t-value) and simultaneously (F-value). Simultaneous test obtained F-value=771.83 with $\operatorname{Pr}>\mathrm{F}=<0.0001(<0.10)$. Therefore, in simultaneous manner, number of beef cattle bred, concentrate cost, number of grass-collection worker, and beef cattle development pattern, were obviously influential to the income of beef cattle breeding.

Coefficient of determination $\left(\mathrm{R}^{2}\right)$ of the model was 0.99133 , meaning that $99.133 \%$ diversities of beef cattle breeding income were explained by number of beef cattle bred, concentrate cost, number of grass-collection 
worker, and beef cattle development pattern, while the remaining $0.867 \%$ were explained by other variable out of the model, and these were vulnerable to error.

The number of beef cattle bred was obviously and positively influencing the income of beef cattle breeding as shown by $\operatorname{Pr}>|t|=<0.0001(<0.10)$. It proved that greater number of beef cattle bred, the higher the income that was obtained from beef cattle breeding.

In other hand, number of grass-collection worker had obvious but negative effect on beef cattle breeding income as shown by $\operatorname{Pr}>|t|=0.030(<0.10)$. Therefore, it could be said that the greater number of grass-collection worker, the lower the income derived from beef cattle breeding.

\section{Model Validation:-}

Model validation was aimed to determine model predictability. Result of model validation would describe how close was the predicted rate with the actual rate, based on endogenous variable observed. The explanation was given in the following table.

Table:- Result of Statistical Test against Model Predictability Rate

\begin{tabular}{|c|c|c|c|c|c|c|}
\hline Variable & Label & $\begin{array}{l}\text { Actual } \\
\text { Mean }\end{array}$ & Predicted Mean & $\mathbf{U M}$ & $\mathbf{U S}$ & $\mathbf{U C}$ \\
\hline Grass-collection worker & TKSPRMP & 1.4688 & 1.4677 & 0.00 & 0.13 & 0.87 \\
\hline On-family breeding worker & TKSPDKL & 1.9063 & 1.9063 & 0.00 & 0.18 & 0.82 \\
\hline Concentrate cost & BKONSP & 5554.7 & 5557.8 & 0.00 & 0.12 & 0.88 \\
\hline $\begin{array}{l}\text { Off-family rice-field farming } \\
\text { worker }\end{array}$ & TKUTLKL & 0.1875 & 0.0418 & 0.16 & 0.26 & 0.58 \\
\hline $\begin{array}{l}\text { On-family rice-field farming } \\
\text { worker }\end{array}$ & TKUTDKL & 1.5313 & 1.1016 & 0.21 & 0.24 & 0.55 \\
\hline Rice-field fertilizer cost & PPKUT & 156110 & 156112 & 0.00 & 0.22 & 0.78 \\
\hline Income from rice-field farming & REUT & 7871263 & 7442892 & 0.04 & 0.47 & 0.49 \\
\hline $\begin{array}{l}\text { Off-family garden farming } \\
\text { worker }\end{array}$ & TKBUNLKL & 0.3438 & 0.2706 & 0.02 & 0.25 & 0.73 \\
\hline $\begin{array}{l}\text { On-family garden farming } \\
\text { worker }\end{array}$ & TKBUNDKL & 1.2813 & 1.2812 & 0.00 & 0.33 & 0.67 \\
\hline Income from garden farming & REBUN & 2696151 & 2662506 & 0.00 & 0.11 & 0.89 \\
\hline Income from breeding & RESP & 24218.8 & 24220.5 & 0.00 & 0.00 & 1.00 \\
\hline Family income & REKL & 11384108 & 9313169 & 0.34 & 0.20 & 0.46 \\
\hline Income from garden field & KBUN & 2953125 & 2405533 & 0.19 & 0.16 & 0.65 \\
\hline Total cost of rice-field farming & TBUT & 547487 & 547489 & 0.00 & 0.00 & 1.00 \\
\hline Income from rice-field & KUT & 8418750 & 6895404 & 0.30 & 0.37 & 0.33 \\
\hline Garden farming worker & TKBUN & 1.625 & 1.5518 & 0.01 & 0.23 & 0.76 \\
\hline
\end{tabular}

Source: Analysis on Primary Data, 2016

Note:

$\mathrm{UM}=$ biased proportion

$\mathrm{US}=$ variance proportion

$\mathrm{UC}=$ covariance proportion

Based on test statistic, predictability criteria included UM, US and UC scores. As shown in the table, most UM scores tended to approach zero, and therefore, the model did not experience systematic bias. In addition, US scores also approached zero, meaning that its predicted rate always followed the fluctuation of actual rate. In other side, model validation showed that most UC scores were approaching to one. In other words, model error was negligent and irregular, but it dispersed to all observation data. From these results of model validation, it could be said that the resultant model was valid to be used as simulation tool.

\section{Analysis on The Change of Input to Beef Cattle Breeding:-}

The simulation of the policy for beef cattle breeding involved various policies. These concerned with feed and nonfeed consumption, the production cost for beef cattle breeding, and the cost of rice-field farming. 


\section{Simulation of the Policy for Feed and Non-Feed Consumption}

The policy that was used in the simulation was to provide the financial aid for feed and non-feed consumption which

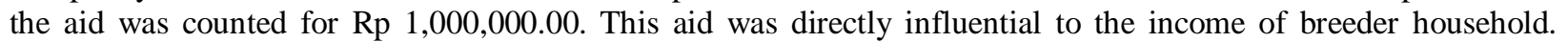
Result of the simulated policy was displayed in the table.

Table:-Simulation of the Policy for Feed and Non-Feed Consumption with Financial Aid of Rp. 1,000,000.00

\begin{tabular}{|l|c|c|c|}
\hline \multicolumn{1}{|c|}{ Variable } & Base Simulation & Simulation Scenario & Change \\
\hline Grass-collection worker & 1.4677 & 1.4683 & $0.04 \%$ \\
\hline On-family breeding worker & 1.9063 & 1.9109 & $0.24 \%$ \\
\hline Concentrate cost & 5557.8 & 5557.8 & $0.00 \%$ \\
\hline Green feed cost & 8414.1 & 8414.1 & $0.00 \%$ \\
\hline Off-family rice-field farming worker & 0.0418 & 0.063 & $50.72 \%$ \\
\hline On-family rice-field farming worker & 1.1016 & 1.1171 & $1.41 \%$ \\
\hline Rice-field fertilizer cost & 156112 & 163018 & $4.42 \%$ \\
\hline Income from rice-field farming & 7442892 & 7505239 & $0.84 \%$ \\
\hline Off-family garden farming worker & 0.2706 & 0.2813 & $3.95 \%$ \\
\hline On-family garden farming worker & 1.2812 & 1.2812 & $0.00 \%$ \\
\hline Income from garden farming & 2662506 & 2667406 & $0.18 \%$ \\
\hline Income from breeding & 24220.5 & 24219.6 & $0.00 \%$ \\
\hline Family income & 9313169 & 9373510 & $0.65 \%$ \\
\hline Income from garden field & 2405533 & 2410432 & $0.20 \%$ \\
\hline Total cost of rice-field farming & 547489 & 554395 & $1.26 \%$ \\
\hline Income from rice-field & 6895404 & 6950845 & $0.80 \%$ \\
\hline Garden farming worker & 1.5518 & 1.5625 & $0.69 \%$ \\
\hline
\end{tabular}

Source: Analysis on Primary Data, 2016

Table above explained that the aid would reduce feed and non-feed consumption but it increased off-family ricefield farming worker to $50.72 \%$, rice-field fertilizer cost to $4.42 \%$, off-family garden farming worker to $3.95 \%$ and total cost of rice-field farming to $1.26 \%$. The income of rice-field farming increased to $0.84 \%$, so did garden farming worker and income from rice-field, which each increased to $0.69 \%$ and $0.80 \%$. Other variable with value less than $0.50 \%$ was subjected to the change. Based on this simulation, there was subsidy given to feed and non-feed consumption to encourage breeders to use off-family worker. Family member migth be put in the other job that was more productive, or that was focusing more in education background rather than merely helping the farming and breeding works.

\section{Simulation of the Policy for Beef Cattle Breeding Cost:-}

In addition to the simulated policy for feed and non-feed consumption, other simulation was to provide financial aid of Rp 1,000,000.00 to reduce beef cattle breeding cost, especially for concentrate cost and green feed cost. Result of simulation was displayed in the table.

Table:-Simulation of the Policy for Beef Cattle Breeding Cost with Financial Aid of Rp. 1,000,000.00

\begin{tabular}{|l|r|r|r|}
\hline \multicolumn{1}{|c|}{ Variable } & Base Simulation & Simulation Scenario & \multicolumn{1}{c|}{ Change } \\
\hline Grass-collection worker & 1.4677 & 1.4683 & $0.04 \%$ \\
\hline On-family breeding worker & 1.9063 & 1.9109 & $0.24 \%$ \\
\hline Concentrate cost & 5557.8 & 4075.8 & $-26.67 \%$ \\
\hline Green feed cost & 8414.1 & 7414.1 & $-11.88 \%$ \\
\hline Off-family rice-field farming worker & 0.0418 & 0.063 & $50.72 \%$ \\
\hline On-family rice-field farming worker & 1.1016 & 1.1171 & $1.41 \%$ \\
\hline Rice-field fertilizer cost & 156112 & 163018 & $4.42 \%$ \\
\hline Income from rice-field farming & 7442892 & 7505239 & $0.84 \%$ \\
\hline Off-family garden farming worker & 0.2706 & 0.2813 & $3.95 \%$ \\
\hline On-family garden farming worker & 1.2812 & 1.2812 & $0.00 \%$ \\
\hline Income from garden farming & 2662506 & 2667406 & $0.18 \%$ \\
\hline Income from breeding & 24220.5 & 24190.4 & $-0.12 \%$ \\
\hline
\end{tabular}




\begin{tabular}{|l|r|r|r|}
\hline Family income & 9313169 & 9373510 & $0.65 \%$ \\
\hline Income from garden field & 2405533 & 2410432 & $0.20 \%$ \\
\hline Total cost of rice-field farming & 547489 & 554395 & $1.26 \%$ \\
\hline Income from rice-field & 6895404 & 6950845 & $0.80 \%$ \\
\hline Garden farming worker & 1.5518 & 1.5625 & $0.69 \%$ \\
\hline
\end{tabular}

Source: Analysis on Primary Data, 2016

Table above illustrated that the financial aid for beef cattle breeding at Rp1,000,000.00 would decrease average concentrate cost for $26.67 \%$ and also reduce green feed cost for $11.88 \%$. This aid did not improve breeder income because income from breeding had declined by $0.12 \%$. Such condition was caused by a tendency of breeders to use off-family worker after receiving the financial aid for beef cattle breeding cost. Therefore, average income from the breeding decreased. In other hand, income from other farming (rice-field farming and garden farming) increased for $1.26 \%$ and $0.20 \%$. General income of the family also improved by $0.65 \%$.

\section{Simulation of the Policy for Rice-Field Farming Cost:-}

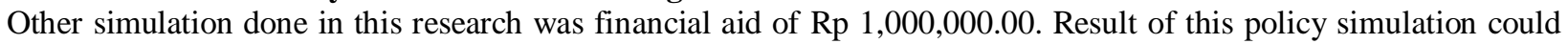
be seen in the table.

Table;- Simulation of the Policy for Rice-Field Farming Cost with Financial Aid of Rp. 1,000,000.00

\begin{tabular}{|l|c|c|c|}
\hline \multicolumn{1}{|c|}{ Variable } & Base Simulation & Simulation Scenario & Change \\
\hline Grass-collection worker & 1.4677 & 1.4683 & $0.04 \%$ \\
\hline On-family breeding worker & 1.9063 & 1.9109 & $0.24 \%$ \\
\hline Concentrate cost & 5557.8 & 5557.8 & $0.00 \%$ \\
\hline Green feed cost & 8414.1 & 8414.1 & $0.00 \%$ \\
\hline Off-family rice-field farming worker & 0.0418 & 0.2253 & $439.00 \%$ \\
\hline On-family rice-field farming worker & 1.1016 & 1.6007 & $45.31 \%$ \\
\hline Rice-field fertilizer cost & 156112 & 163018 & $4.42 \%$ \\
\hline Income from rice-field farming & 7442892 & 7982464 & $7.25 \%$ \\
\hline Off-family garden farming worker & 0.2706 & 0.3628 & $34.07 \%$ \\
\hline On-family garden farming worker & 1.2812 & 1.2812 & $0.00 \%$ \\
\hline Income from garden farming & 2662506 & 2704907 & $1.593 \%$ \\
\hline Income from breeding & 24220.5 & 24219.6 & $0.00 \%$ \\
\hline Family income & 9313169 & 12138236 & $30.33 \%$ \\
\hline Income from garden field & 2405533 & 2447933 & $1.76 \%$ \\
\hline Total cost of rice-field farming & 547489 & 304395 & $-44.40 \%$ \\
\hline Income from rice-field & 6895404 & 8678069 & $25.85 \%$ \\
\hline Garden farming worker & 1.5518 & 1.644 & $5.94 \%$ \\
\hline
\end{tabular}

Source: Analysis on Primary Data, 2016

As noted in table above, financial aid of $\mathrm{Rp} \mathrm{1,000,000.00} \mathrm{that} \mathrm{was} \mathrm{given} \mathrm{to} \mathrm{rice-field} \mathrm{farming} \mathrm{cost} \mathrm{was} \mathrm{contributive}$ to the reduction of total cost of rice-field farming for $44.40 \%$. The aid also improved the earning from rice-field by $7.25 \%$, income from rice-field by $25.85 \%$, income from garden farming for $1.76 \%$, and family income by $30.33 \%$. Significant increase was also found in the off-family rice-field farming worker by rate of $439 \%$ and on-family ricefield farming worker at rate of $45.31 \%$.

\section{Contribution to the Research:-}

\section{Theoretical Contribution:-}

The review on the results of some previous researches had found a surprising fact. The use of simultaneous equation model to understand household economic was still lacking of research. Research about alternative policy to develop household economic in the beef cattle breeding was also not yet delivered.

Chayanov developed a household economic model to help the farmer to allocate production factors owned by the farming household. The decision about production and consumptionm in the farming household was inseparable. Household economic model of the farmers that was formulated by Chayanov was operated by maximizing the utility 
of three items, including: (1) Function of production, (2) Minimally accepted income rate, and (3) Maximum workday at farmer household.

'Research on household economic in the beef cattle breeding attempted to develop Chayanov's theory of household economic model by involving some simultaneous equations and by making connection between these equations and the alternative policies that related with work development. These policies included those about input improvement, process improvement, output management, and consumption change, in order to increase the income of beef cattle breeders.

One of distinctive character from household economic model of farmers was the relationship between decision on production and decision on consumption. In simultaneous equation model, the analysis was done through simulation by experimenting the change of input and output prices. Policy simulation could be operated by exploiting some policy variables (simultaneously) which could impact on farmer household. The benefit of simulation analysis was that it could resolve the problem in non-linear equation in the model where farmer household might have different exogenous variable. Elasticity analysis could help determining the variance of farmer household size (Smith and Strouss, 1986). The analysis against the impact of price change could be also conducted with a combination of more than one policy variable.

\section{Practical Contribution:-}

Simultaneous equation model was useful to simulate few policy alternatives to increase household economic welfare of beef cattle breeders. Result of single simulation indicated that the policy that could increase household income was financial aid of $\operatorname{Rp} 1,000,000.00$ to support rice-field farming cost.

\section{Conclusion And Suggestion:-}

\section{Conclusion;-}

By taking account all the results of research and discussion, it was concluded that:

1. Household economic model that was formulated in this research could explain the behavior in deciding about farming and breeding productions, and this decision was strongly influential to the income of farming household. Some decisions must be made, such as about grass-collection worker, on-family breeding worker, concentrate cost, green feed cost, off-family rice-field farming worker, on-family rice-field farming worker, rice-field fertilizer cost, income from rice-field farming, off-family garden farming worker, on-family garden farming worker, income from garden farming, income from beef cattle breeding, income of the family, income from garden field, total cost of rice-field farming, and income from rice-field farming.

2. Income from beef cattle breeding was influenced by the number of beef cattle bred and the number of grasscollection worker. Concentrate cost remained under influence of the cost to purchase livestock feed greens (HMT). HMT cost itself was influenced by the number of beef cattle bred.

3. If governmental policy was indeed aimed to improve the income of farmer household, then the most effective policy scenario would be the scenario of providing financial aid of Rp 1,000,000.00 for rice-field farming. This aid was allocated to some decisions, which were described at percentage point, such as: Grass-collection worker $(0.04 \%)$; On-family breeding worker $(0.24 \%)$; Cconcentrate cost $(0.00 \%)$; Green feed cost $(0.00 \%)$; Off-family rice-field farming worker $(439.00 \%)$; On-family rice-field farming worker $(45.31 \%)$; Rice-field fertilizer cost $(4.42 \%)$; Income from rice-field farming (7.25\%); Off-family garden farming worker (34.07\%); On-family garden farming worker $(0.00 \%)$; Income from garden farming $(1.593 \%)$; Income from beef cattle breeding $(0.00 \%)$; Income of the family $(30.33 \%)$; Income from garden field $(1.76 \%)$; Total cost of rice-field farming (44.40\%); Income from rice-field farming (25.85\%); and Garden farming worker (5.94\%).

4. If the government could select the proper policy, then policy goal would be matching with the result of this research, respectively the improvement of household income.

\section{Suggestions:-}

There were many policies to be made about food. The recommended food policies for farming-breeding works would be those about the occupied land width, the increase of production through the utilization of production input, the on-family and off-family based employment, and the earning and income of farming-breeding works, and the income of household that would be spent on consumption and investment. 


\section{References:-}

1. Gujarati,D.N. 2001. Basic Econometrics, Third Edition. McGraw Hill. Singapore.

2. Suryana. 2009. Pengembangan Usaha Ternak Sapi Potong Berorientasi Agribisnis Dengan Pola Kemitraan Balai pengkajian Teknologi Pertanian Kalimantan Selatan Jurnal Litbang Pertanian, 28 (1) 2009.

3. Tarmizi H.B dan Safarudin. 2012. Pengaruh Sistem Integrasi Padi Ternak (SIPT) Terhadap Peningkatan Pendapatan Petani Dan Dampaknya Terhadap Pengembangan Wilayah Di Kabupaten Serdang. Jurnal Ekonom 15 (4), Oktober 2012. 